\title{
SEVENTY-FIVE YEARS OF ALBERTA WATER LAW: MATURITY, DEMISE \& REBIRTH
}

\author{
DAVID R. PERCY
}

Water law has been of great importance in Alberta's legal and economic community over the last seventy-five years. By the time the University of Alberta's Faculty of Law first opened its doors in 1921, the reformed law of water allocation had already reached maturity and was showing its first signs of strain. Over the next seventy-five years, the problems that were beginning to emerge in 1827 gradually created irresistible pressures for change until, in 1996, the law of water allocation underwent a further major transformation. The purpose of this article is to describe this evolution in the law of water allocation. The author begins by outlining how the law had developed to maturity by 1921 and the problems that were beginning to emerge at that time. He goes on to explain how those problems finally overwhelmed the existing law by the last decade of the century. Finally, the author sets out the legislative response in the form of the new Water Act of 1996.
Au cours des soixante-quinze dernières années, la loi sur les eaux a pris une importance considérable dans les cercles juridiques et économiques de l'Alberta. En 1921, quand la faculté de droit de l'Université de l'Alberta a ouvert ses portes, la loi modifiée relative à la quantité d'eau allouée avait déjà atteint sa maturité et montrait ses premiers signes de faiblesse. Au cours des soixante-quinze années suivantes, les problèmes qui émergeaient en 1827 ont graduellement créé d'irrésistibles pressions jusqu'en 1996, date à laquelle la loi a subi une autre transformation majeure. L'auteur se propose de décrire l'évolution de cette loi. II explique ensuite comment les problèmes qui se sont manifestés vers 1921 ont fini par submerger la loi au cours des dix dernières années. Finalement, il présente la nouvelle loi de 1996 sur les eaux.

\section{TABLE OF CONTENTS}

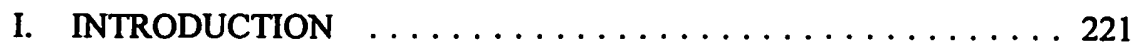

II. THE DEVELOPMENT OF A MATURE SYSTEM

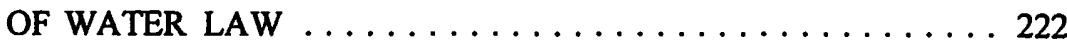

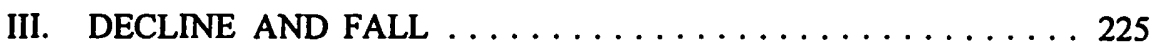

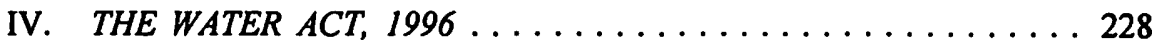

A. CLASSES OF WATER RIGHTS $\ldots \ldots \ldots \ldots \ldots \ldots 228$

B. THE TRANSFER OF WATER RIGHTS $\ldots \ldots \ldots \ldots \ldots 234$

C. ENVIRONMENTAL PROTECTION $\ldots \ldots \ldots \ldots \ldots .237$

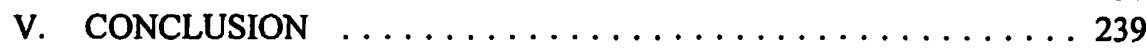

\section{INTRODUCTION}

At first sight, it might seem indulgent to include water law in a survey of the development of Alberta law during the existence of a permanent Faculty of Law at the University of Alberta. Water law did not occupy an independent place in the curriculum of Professor Weir's law school in 1921. The rights of riparian owners in respect of both

Professor of Law, University of Alberta. Professor Percy acted as a consultant to the Drafting Committee for the new Water Act. The views expressed in this article are based on his own knowledge and experience in water management law and do not represent the position of Alberta Environmental Protection or the government of Alberta. The research assistance of Cathy Duxbury and the secretarial assistance of Merle Metke in the preparation of this article are gratefully acknowledged. 
water quantity and water quality were no doubt taught as an adjunct of the Law of Real Property, as they are today, but water law was not a significant element in the curriculum until Dr. Andrew Thompson developed a course in Natural Resources Law in the $1960 \mathrm{~s}$.

Although water law did not form a major part of the business of the Law Faculty over much of the past seventy-five years, it has been of great importance in Alberta's legal and economic history over that period. Disputes over drainage were frequently litigated in the first two decades of Alberta's existence.' Although water pollution may not have been a serious concern at this time, it soon gave rise to a landmark decision on the law of nuisance and the nature of a riparian owner's right to water of a certain quality. ${ }^{2}$ The common law dealing with the right to divert, capture and consume quantities of water - the law of water allocation - had undergone radical reform a quarter of a century before the the Faculty of Law formally opened its doors in 1921 . By that time, the reformed law of water allocation had already reached maturity and was beginning to show the first signs of strain. Over the next seventy-five years, the problems that were beginning to emerge in 1921 gradually created irresistible pressures for change until, in the Faculty's seventy-fifth year, the law of water allocation underwent a further major transformation.

The purpose of this article is to describe this evolution in the law of water allocation. Part II will outline how the law had developed to maturity by 1921 and the problems that were beginning to emerge even at that time. Part III will explain how those problems finally overwhelmed the existing law by the last decade of the century and Part IV will set out the legislative response in the form of the newly minted Water Act of 1996.

\section{THE DEVELOPMENT OF A MATURE SYSTEM OF WATER LAW}

When European agricultural settlement of the prairies began, one of the first major legal objectives of the Government of Canada was to ensure that settlers obtained secure legal title to land through the Dominion Lands Act of $1884 .^{3}$ The arid natural conditions of the southern prairies soon emphasized that security of tenure did not mean security of crops. The common law doctrine of riparian rights which prevailed at that time 4 allowed only those who owned lands adjoining a watercourse to use water and thus sterilized land distant from water. The doctrine restricted the development of even riparian land, by limiting the right of riparian owners to the use of water for domestic purposes and allowing its use for extraordinary, non-domestic purposes only if the Environmental Law Centre Society, 1993) at 13-18 for a discussion of the development of the common law of drainage.

2 Groat v. City of Edmonton, [1928] S.C.R. 522.

3 Dominion Lands Act, R.S.C. 1884, c. 54.

4 For a full description of the problems involved in the application of riparian rights on the prairies see D.R. Percy, "Water Rights in Alberta" (1977) 15 Alta. L. Rev. 142 at 155-63. 
quantity they consumed did not perceptibly diminish the natural flow of the watercourse.

Early agricultural settlers were more concerned with the imperatives of survival than the niceties of the law of riparian rights. John Glen had instituted the first recorded use of water for irrigation in Alberta in 1879, on Fish Creek, just south of Calgary. The arrival in southwestern Alberta of Mormon settlers, who had experience of irrigation techniques in Utah, provided the impetus for a growing irrigation movement, which was further encouraged by the onset of a prolonged drought in 1887 . This growth awakened the previously latent conflict between irrigation and riparian rights and the threat that large scale irrigation might be prevented by an injunction alarmed Charles Card, the Mormon leader. Card's concerns found a sympathetic ear in William Pearce, the Superintendent of Mines for the Department of the Interior in Regina, who felt that agriculture in the southern prairies was doomed to failure unless common law riparian rights were curtailed. ${ }^{6}$

The movement to reform the common law culminated in the passage of the NorthWest Irrigation Act in 1894. The Act adopted a scheme for the allocation of water similar to that which had been used for the disposition of other natural resources in Western Canada. Its cornerstone was a declaration that the property in and the right to the use of all water was vested in the Crown. ${ }^{7}$ Having secured control of the resource, the Crown then allocated the right to divert and use water to those who obtained a licence, which allowed the holder to use the amount of water allocated on the land described in the licence. The $A c t$ thus removed the restrictions of the common law of riparian rights both on the quantity of water that could be used and on the location of water use, because licences could be granted for all land, whether or not it adjoined a watercourse. The Act did not set out any maximum duration for licences and in practice they were granted without term until very recent times and treated as perpetual in nature.

The exact nature of the right of the riparian owner to use water for non-domestic purposes in Canada is unclear. In G.V. LaForest, Water Law in Canada: The Atlantic Provinces (Ottawa: Information Canada, 1973) at 209, the "reasonable use" version of the riparian rights doctrine is stated as follows:

[A] riparian owner is entitled to the reasonable use of water in a stream on or adjoining his land, and in making such use [the courts] recognize that he must, in many cases, of necessity affect the flow downstream.

The version of the doctrine stated in the text is the so-called "natural flow" theory, which prevailed in 19th century England and was modified by the courts of the maritime provinces, probably out of necessity in order to accommodate significant uses of water. Technically, the natural flow theory may well have applied in Alberta in the late nineteenth century: supra note 4. E.A. Mitchner, William Pearce and Federal Government Activity in Western Canada, 1882-1894 (Ph.D. Thesis, University of Alberta, 1971) at 197 [unpublished]; House of Commons Debates, (25 June 1984) at 4952.

7 The original Irrigation Act, S.C. 1894, c. 30 merely vested the right to the use of water in the Crown, following Australian precedent. In 1895, this section was retroactively amended to vest in the Crown both the property in and the right to the use of all water: An Act to Amend the Northwest Irrigation Act, S.C. 1895, c. 33, s. 2. 
The Act also revolutionized the manner in which water was distributed during times of shortage. The riparian doctrine was a product of geographical conditions in which water was plentiful and in effect it allowed all riparians to take water for domestic and allowable extraordinary purposes if they could obtain a supply. As a result, on seasonal streams, for example, upstream riparians might consume all the available water in the ordinary exercise of their rights before it ever reached downstream users. In contrast, if there was insufficient water in a river or lake to satisfy all licensed users, the NorthWest Irrigation Act distributed water among licensees according to the principle of first in time, which was adopted from the American law of prior appropriation. During shortages, the supply of water could be terminated according to the seniority of the licence, so that the water allocation of the most recent licensee would be cut off first. If there was still insufficient water to satisfy the remaining licensed users, the supply of the next junior licensee would be cut off and in theory the process could continue in reverse order of seniority until only the senior licensee had access to water. ${ }^{8}$

The legislation also left certain vestigial rights to riparian owners, although their extent has always remained controversial. Despite the confident assertion that the initial Act was based on "the total suppression of riparian rights,"" it was clear for over ninety years that the riparian right to use water for domestic purposes as defined in the legislation was largely unaffected. ${ }^{10}$ In addition, the Act could not impair other aspects of riparian rights, such as the right to water of a certain quality and the right of access to the watercourse, which it did not even mention. It is probable that riparian owners retained the right to sue in respect of both unlicensed diversions and diversions that exceeded the terms of a licence," although some startlingly opposed judicial pronouncements make it difficult to draw broad conclusions with great confidence. ${ }^{12}$

By 1921, the Irrigation Act ${ }^{13}$ had accomplished its initial goal of encouraging agricultural settlement by providing secure water rights to those who could put water

North-west Irrigation Act, S.C. 1894, c. 30, s. 19.

"General Report on Irrigation in the Northwest Territories (1894)" in Annual Report of the Department of the Interior (1895) at 28. See also House of Commons Debates (25 June 1896) at 4950, T. Mayne Daly. The confusion over riparian rights is perhaps best described by Burchill, "The Origins of Canadian Irrigation Law" (1948) 29 Can. Historical Review 353, who commented that this aspect of the $A c t$ was understood neither by the Minister who sponsored the Bill nor by the members of the Parliament which approved it.

The legislation long stated that the provisions of the Act "do not affect the right" of a riparian to the use of water for domestic purposes: Water Resources Act, R.S.A. 1970, c. 388, s. 5(4). Since 1981, the $A c t$ has merely stated that it does not require a riparian owner to obtain a licence for domestic use. The Water Resources Amendment Act, 1981, S.A. c. 40, s. 3.

Percy, supra note 4 at $155-63$.

See $R$ v. Very, [1983] 6 W.W.R. 143 (Alta. Q.B) [hereinafter Very] where Egbert J. commented that riparian rights "have been completely taken from the riparian owner by the Water Resources Act." In Re Tottrup and the Queen (1979), 102 D.L.R. (3d) 42 (Alta. C.A.), leave to appeal denied (1979), 19 A.R. 188 (S.C.C.), the majority of the court found that a riparian's right to protect his land against flood was not affected by the Water Resources Act in the absence of clear and explicit language. This approach suggests that a number of other riparian rights, such as those set out in the text, also survive, though the dissenting judgment of Prowse J.A. takes a view similar that of Egbert J. in the Very case: ibid. at 52.

The name of the legislation was changed to the Irrigation Act, R.S.C. 1906, c. 61 . 
to productive use. The fact that it contained a fatal flaw was not obvious as long as there was sufficient water available for allocation to new users, but the scheme of giving out water licences without term on a first-come, first-served basis inevitably meant that the demand for water would soon outstrip supply. This consequence became evident in the summer of 1919 , when federal administrators were concerned that a shortage of water was developing. They were aware that most of the available water rights in southern Alberta were likely to be taken up by irrigation and that it would be difficult for expanding municipalities to secure a supply of water that would be adequate for their increasing needs. As the Minister of the Interior pointed out, under the legislation, once "the water right is gone ... there is no provision for recovering it."14

Federal administrators appeared to assume that the Irrigation Act did not allow the transfer of a water right from an existing licensee to a new user, ${ }^{15}$ although this rule was not expressly enacted until the first provincial Water Resources Act in $1931 .{ }^{16}$ A new user could acquire an existing water right only by obtaining the land of an existing licensee and continuing to use water for the same purpose. In an effort to cure this problem, the $A c t$ was amended in 1920 to create a list of preferential uses, which gave the highest priority to the use of water for domestic purposes, followed in order by its use for municipal, industrial, irrigation and other purposes. ${ }^{17}$ The only real importance of the list of preferential uses is to permit a person who requires water for a higher priority purpose to apply for the cancellation of a licence that has been issued for a lower priority purpose. If compensation for the cancellation of the inferior licence cannot be agreed, the administrator is authorized to fix the compensation and to issue a licence to the new user with the same priority as the cancelled licence. This system essentially allows the purchase and, if necessary, the expropriation of licences to use water for lower priority purposes, subject to administrative approval. It permits, for example, a municipality to obtain water from an industrial user or an irrigator, but not vice versa. It created a safety valve which can enable municipalities and other higher priority users to obtain secure water rights, but one which has rarely, if ever, been used in practice.

\section{DECLINE AND FALL}

The amendment of the Irrigation Act in 1920 created an immediate solution to the pressing problem of the time. However, the solution merely disguised the fundamental

House of Commons Debates (17 June 1920) at 3695.

D.R. Percy, The Framework of Water Rights Legislation in Canada (Calgary: Canadian Institute of Resource Law, 1988) at 23-24.

Water Resources Act, S.A. 1931, c. 71, s. 18. The equivalent section is now found in the Water Resources Act, R.S.A. 1980, c. W-5, s. 23 [hereinafter Water Resources Act].

Irrigation Act, S.C. 1920 , c. 55, s. 4. In 1975, irrigation and other agricultural purposes moved ahead of industrial purposes: Water Resources Amendment Act, S.A. 1975, c. 88, s. 7; and water power purposes was added as the fifth priority ahead of other purposes: An Act to amend The Water Resources Act, S.A. 1941, c. 99, s. 4; see also Part III, below. The table also applies in the unlikely event that two applications for water resources are received on the same day: Water Resources Act, ibid. s. 11(3). 
nature of the problem and postponed the need for dealing with it more comprehensively. Its enactment signalled that Alberta water law had now reached its mature state. The law provided a workable system that had allocated secure water rights throughout the dry belt and contained a mechanism which allowed the transfer of water to higher priority uses in tightly defined circumstances.

It became clear over the next half century that the restricted system for the transfer of water rights adopted in 1920 was no cure for the rigid patterns of water use that the Irrigation Act had created. The list of statutory priorities answered only the need to ensure that municipalities could obtain water and did not constitute a serious attempt to reflect the importance of different types of water use. Even if the list had accurately recorded the social preferences in water use of 1920, it did not allow for changes in those preferences over time or for the existence of other priorities in regions whose geographical and climatic characteristics differ radically from those of southern Alberta. ${ }^{18}$

The Act continued to exist in a virtually unchanged form when Alberta assumed control of water as a result of the Natural Resources Transfer Agreement of 1930.19 In 1975, a change in the table of preferential uses moved the use of water for irrigation and other agricultural purposes to third position, ahead of industrial purposes. ${ }^{20}$ This amendment further reduced the practical likelihood that water would be provided to new users and entrenched the virtual guarantee that the Act will cause water shortages in the arid regions of Alberta.

The legislation also contributes to water shortages in less obvious ways. The secure water rights enjoyed by existing licensees were granted either without fee or for a nominal initial charge. A licensee thus does not achieve any saving in cost by reducing consumption and making water available to new users. Indeed, there is a total absence of incentive for existing users to conserve water. Most conservation methods, such as the installation of water meters within municipalities or of modern irrigation equipment, impose on licensees extra costs which cannot be recouped, because the restrictions on transfers outside the table of preferential uses prohibit licensees from disposing of conserved water to others. In economic terms, because the Act fails to allow for the recognition of the marginal value of water, it tends to encourage licensees to consume as much water as possible in their operations, if they can thereby minimise the cost of other inputs for which they are required to pay a price. ${ }^{21}$

For a more detailed critique, see D.R. Percy, "Water Rights Law and Water Shortages in Westem Canada" (1986) 11:2 Can. Water Res. J. 14 at 19.

19 British North America Act, 1930 (U.K.), 21 Geo. 5, c. 26. Initial doubts as to whether the resources transferred to the Province included water were resolved by retroactive legislation in 1938: Natural Resources Transfer (Amendment) Act 1938, S.C. 1938, c. 36; An Act to Ratify a certain Agreement between the Government of the Dominion of Canada and the Government of the Province of Alberta, S.A. 1938, c. 14.

21 See Gysi, "Measuring the Need for Inter-Basin Transfers" (Paper presented to a Conference on Inter-Basin transfers, University of Alberta, Edmonton, Alberta, 27-28 August 1980 [unpublished]). 
The Water Resources Act thus fails to make room for new users in fully allocated basins, or allows them at most to obtain insecure junior water licences, and fails to create any incentive to conserve water. The true nature of these problems, however, took some time to emerge. Alberta's response to the need to accommodate new water users was to increase the supply of water through storage. In 1975, Environment Canada noted that over $\$ 1$ billion had been expended on storage facilities in the Saskatchewan-Nelson River Basin, much of it in Alberta. Even after that expenditure, it warned that the future development of the basin might be limited "by its ability to supply water for its expanding and diverse activities which are continually consuming more of the available supply."22 Since 1975 , more major projects, such as the Oldman River Dam, have added to the total expenditures on water storage in the Alberta portion of the basin. While other potential water storage projects exist, it is probably safe to conclude that the most favourable sites in the basin have already been exploited. As the possibilities of water storage became less economically feasible, studies began to consider the augmentation of natural water supply by the transfer of water from the major northward flowing river basins to the arid south. This movement probably reached its zenith with the publication of a large study in 1972, which considered numerous potential inter-basin transfers within Alberta and throughout the prairie provinces..$^{23}$ Even at that time, however, the Report concluded that large supplies of water could be made available to the Saskatchewan-Nelson basin only "with major expenditures" and that "the potential costs in improving waters supplies were large." ${ }^{24}$

The option of increasing water supplies through inter-basin transfers has virtually disappeared from the public agenda, perhaps through a combination of the high costs involved and apprehension about their environmental consequences. As the next section will show, the new Water Act expressly prohibits the transfer of water between major river basins. ${ }^{25}$ The major controversy and unprecedented litigation that accompanied the construction of the Oldman Dam, together with economic realities, seem to have reduced the enthusiasm for large water storage projects. These changing attitudes led to a recognition in the early stages of the water law reform process of the need to consider the transferability of water rights ${ }^{26}$ and a change in the focus of water management "from strict allocation to recognition of the true value of water resource

Canada Water Year Book (Ottawa: Environment Canada, 1975) at 48.

Saskatchewan-Nelson Basin Board, Canada, Alberta Saskatchewan, Manitoba, "Water Supply for the Saskatchewan-Nelson Basin" (Saskatoon: Saskatchewan-Nelson Basin Board, 1972). See the summary of storage and diversion possibilities in Alberta, ibid. at 48-49. See also Nature's Lifeline: Prairie and Northern Waters (Canada West Foundation, 1982) at 64-67 for a summary of storage and diversion projects. The idea of inter-basin transfers was briefly revived at the tum of the decade. See "Dryland Kroeger Turns Back the Clock, A Decade-old Massive Water project is Revived by the Tories" Alberta Report (30 November 1979) at 27-30.

"Water Supply for the Saskatchewan-Nelson Basin," supra note 23 at 185.

See Part IV below.

Water Management in Alberta, Challenges for the Future (Edmonton: Alberta Environment) at 16. 
through its conservation and management in accordance with the goals of sustainable development. ${ }^{\text {.27 }}$

The role of the Water Resources Act in creating and perpetuating water shortages was not the only reason for reform. Over its long life, Alberta's water legislation had been frequently amended, usually in response to the emergence of specific issues in water management. By the time that the Legislature ordered euthanasia in 1996, the Act resembled an accident victim in a cartoon, entirely swathed in bandages to cover individual problems and its total shape visible only in outline. The piecemeal approach to amendment, however, had left unsolved many basic questions. As indicated earlier, ${ }^{28}$ the nature and extent of riparian rights remained controversial. Further confusion was created when ground water was brought under the Act in $1962 .{ }^{29}$ The Act gave little explicit recognition to environmental issues and water management planning $^{30}$ and, although it dealt with a critical resource, there was no link between the Act and Alberta's comprehensive Environmental Protection and Enhancement Act. The following section of this article will outline the manner in which the new Water Act deals with each of these problems.

\section{THE WATER ACT, 1996}

On August 27, 1996, the Legislature passed the Water $A c t^{31}$ and brought to a final conclusion seven years of public consultation through workshops, open houses, and various other forums in which every aspect of water management was thoroughly aired. For the purposes of the present article, the discussion will show how the new Act deals with the fundamental problems of the Water Resources Act through an outline of the classes of water right created by the new $A c t$, including those held by riparian owners and users of ground water, the transfer of water rights, and provisions for environmental protection and water planning.

\section{A. CLASSES OF WATER RIGHTS}

The new Act creates four categories of water rights holders: existing licensees, household users, traditional agricultural users and new licensees.

Newsletter, "Water Management Policy and Legislation Review" (Edmonton: Alberta Environmental Protection, undated) at 3, issued with the publication of the Water Management in Alberta: Challenges For the Future: Discussion Draft of Legislation (Edmonton: Alberta Environmental Protection, 16 August 1994). At this stage, it had become clear that the fundamental problems inherent in the Water Resources Act required a fundamental reappraisal. 


\section{Existing Licensees}

As the discussion earlier in this article showed, water rights have vested in licensees for over a century and have been treated as perpetual in nature. From the beginning of the reform process, the government emphasised that existing water rights would be protected. $^{32}$ This commitment is carried out by s.18, which states that all existing licences are "deemed licences" under the new Act and carry their original priority number. ${ }^{33}$ Deemed licensees can continue to divert water in accordance with their original priority, the terms and conditions of their original licence and the new $A c t .^{34}$ However, if there is a conflict between a term of a deemed licence and the new Act, the term of the licence prevails over the Act. Thus, for example, many modern licences on the South Saskatchewan River are subject to a requirement that the diversion of water shall not be permitted unless a minimum residual flow of 1500 cubic feet per second is maintained in the river. ${ }^{35}$ The licensee is entitled to observe the minimum flow requirement specified in its licence, even if the Minister were to require a higher minimum flow in the river under the new Act. Existing licensees are thus amply protected, as are those who may have obtained water rights under instruments of varying degrees of formality which were issued under predecessor legislation. ${ }^{36}$ Correspondingly, the inability to interfere with deemed licences means that it remains difficult to impose minimum instream flows in fully allocated rivers, although an opportunity to do so is created by the new provisions allowing for the transfer of water rights. ${ }^{37}$

\section{Household Users}

It will be recalled that riparian users of water for domestic purposes were accorded a measure of protection under the 1894 North-West Irrigation Act and its successors, though the extent of that protection was often controversial. ${ }^{38}$ The preservation of this aspect of riparian rights created administrative problems in water-short areas, because it was difficult to quantify with any precision the amount of water which a riparian could use for domestic purposes. Under the Water Resources Act, the definition of "domestic purposes" allowed the use of water for "household requirements, sanitation and fire prevention, the watering of domestic animals and poultry and the irrigation of a garden not exceeding one acre. ${ }^{139}$ Not surprisingly, domestic users were inclined to have an expansive view of the amount of water to which they were entitled under this

See e.g. Water Management in Alberta, Discussion Draft of Legislation (Edmonton: Alberta Environmental Protection, 1994) [hereinafter Discussion Draft].

Water Act, supra note 31, s. 18(1).

Water Act, ibid., s. 18(2)(b).

See e.g. Licence No. 19779 issued pursuant to the Water Resources Act on December 7, 1993.

The Water Act, supra note 31, s. 18(6). Under ibid., s. 18(4)(c)(d), temporary permits, permissions for temporary diversion and interim licences can, by Ministerial order, become deemed licences or deemed preliminary certificates under the new Act.

See Part IV.B below.

See text accompanying note 9 .

Water Resources Act, supra note 16, c. W-5, s. 1(g). 
section and on occasion to claim that the right to water domestic animals allowed them to maintain and water large herds of cattle without a licence.

Throughout the discussion of the reform of water law, the consistent approach was to attempt to quantify the right to domestic use, to rename the right in order to avoid confusion with the old regime and to specify the relationship between the Act and riparian rights. In early versions of the new legislation, it was suggested that the right to use water without a licence for household and related purposes should be restricted to fifty cubic metres of water per week and 2,500 cubic metres (equivalent to two acre feet) per year. ${ }^{40}$ However, following the recommendations of a Water Management Review Committee, which represented a broad range of interest groups, it was decided to treat the former agricultural component of domestic use separately (under the heading of traditional agricultural use) and to limit the right to use water for purely household purposes to 1250 cubic metres (one acre foot) per year. ${ }^{41}$ The new Act thus allows any riparian to divert this quantity of water for household purposes without a licence and makes it clear that a licence cannot be obtained for this type of water use. ${ }^{42}$ It also emphasizes that the legislation does not affect those aspects of riparian rights that do not relate to the continued flow of water. ${ }^{43}$

The new Act provides the same right to use water for household purposes to a person "who owns or occupies land under which ground water exists, ${ }^{44}$ whose legal position had been extremely insecure even after ground water was brought under the Water Resources Act in $1962 .^{45}$ Under the existing Water Resources Act, it is clear that a person who wishes to divert ground water for non-domestic purposes must obtain a licence, just as if the diversion were of surface water, and that users of ground water for domestic purposes, like riparians, are not required to obtain a licence.

The apparent simplicity of this scheme ignores the fact that the legal positions of domestic users of ground water and of riparians under the Act are vastly different. Both at common law and after the passage of the North-West Irrigation Act, riparian owners held a well protected right to water for domestic purposes. ${ }^{46}$ In contrast, at common law, domestic users could use ground water only if they could capture it and under the law of capture they enjoyed no security if a neighbour interfered with their supply of ground water, ${ }^{47}$ even intentionally. ${ }^{48}$ The extension of the Water Resources Act to

Discussion Draft, supra note 32, s. 1(x), 25(1).

Report of the Water Management Review Committee (Edmonton: Alberta Environmental Protection, July 1995) at 29.

Water Act, supra note 31, s. 21(1). It should be noted that under ibid, s. 21(3), the number of households on a parcel of land for the purpose of determining the total amount of water that can be used for household purposes can be limited.

Ibid., s. 22(3).

Ibid., s. 21(2).

An Act to amend The Water Resources Amendment Act, S.A. 1962, c. 99, s. 2. The problems of integrating ground water with the Act are described in D.R. Percy, The Regulation of Ground Water in Alberta (Edmonton: Environmental Law Centre, 1987) at 8-13.

See text accompanying notes $9,10$.

Chasemore v. Richards, [1859] 7 H.L.C. 349, 11 E.R. 140.

As in the celebrated case of Bradford Corporation v. Pickles, [1895] A.C. 587. 
cover ground water did nothing to increase the legal rights of domestic users, although administrative practice under the Act gave a measure of practical protection to their position. ${ }^{49}$ It was soon recognized that unlicensed domestic users of ground water had no cause of action if their supply of water was impaired by other users, whether licensed or not, ${ }^{50}$ because the Act had not increased their common law rights.

The Discussion Draft of the new legislation vastly improved this legal position by granting to land owners for the first time a secure right to divert ground water for household purposes and by providing that this right has priority over any diversion by a licensee. ${ }^{\mathrm{si}}$ Thus, under the scheme ultimately adopted in the Water Act, a household user of ground water whose supply is impaired, for example, by licensed wells in a neighbouring residential subdivision, has a protected right to water far greater than that enjoyed either under the Water Resources Act or the common law. The disadvantage, of course, is that the right to use water for household purposes without a licence is now limited to one acre foot per year. ${ }^{52}$ Any use of ground water beyond that amount requires a licence.

At the time that the Discussion Draft was circulated, when the right to divert for household purposes would have allowed the use of two acre feet of water per year, ${ }^{53}$ this suggestion was highly controversial in the rural community, probably because few people realized that their right to use ground water without a licence was legally insecure. There was little recognition of the fact that the proposed legislation provided legal protection to household use for the first time, because many people assumed that they already had that protection and that they could divert large quantities of water under a generous interpretation the domestic use provisions of the Water Resources Act. The Discussion Draft became a focus of discontent, because it was seen as requiring "thousands of Alberta farmers to obtain water licences." ${ }^{54}$ This statement was literally true, because licences are now clearly required for uses other than for household purposes, but it neglects the fact that the purpose of licences is as much to provide rights as to regulate licensees. Under the Water Resources Act, any user of ground water should obtain a licence, because the licence is the only method of obtaining any security to ground water, even for domestic users. The new $A c t$ retains that security and in addition provides protection for unlicensed household use.

The decision to restrict both riparian owners and ground water users to one acre foot of water per year for household purposes created a need to give statutory recognition to agricultural uses of water that require more than that amount, which could formerly be carried on without a licence on a generous interpretation of the domestic use

See Percy, supra note 45 at 13-18.

Schneider v. Town of Olds (1970), 8 D.L.R. (3d) 680 (Alta. S.C.).

Discussion Draft, supra note 32, s. 25(3).

See supra note 41 and accompanying text.

See supra note 40 and accompanying text.

W.B. Russell \& I.K. Wilson, Report on the Impacts of the Discussion Draft of the Water Conservation and Management Act on the Agriculture and Livestock Industry (Edmonton: Bishop \& McKenzie, 1994) at 9. 
provisions. In the Water Act, this recognition involves the creation of a third type of water user, known as the traditional agricultural user.

\section{Agricultural Users}

The objection that the proposed legislation imposed on existing unlicensed domestic users the onerous bureaucratic burden of obtaining a licence resulted in the suggestion by the Water Management Review Committee that some agricultural uses of water should be exempt from licensing requirements. ${ }^{55}$ This recommendation is reflected in the Water Act, which allows riparians or ground water users who, when the Act comes into force, are using water for the purpose of raising farm animals or applying pesticides to crops as part of a farm unit, to continue to divert up to 6250 cubic metres (five acre feet) of water for those purposes without a licence. ${ }^{56}$ Exempt agricultural users can thus continue to divert up to five acre feet of water per year (or any a greater amount that may be specified in an approved management plan) without committing an offence under the Act. If they also qualify as household users of water, they may rely on their household entitlement to divert up to a total of six acre feet without a licence.

The exemption from licensing is one response to a problem caused by the fact that while in some parts of Alberta water supplies can be desperately short, in other regions supplies are plentiful, or even excessive. Agricultural users in regions where there are no water shortages, or where water is collected in dugouts on the farm, may choose not to obtain any authorization for their water use under the Water Act. However, if they choose this option, they have no priority to water if a shortage subsequently develops. Thus, if an unexpected drought or regional shortage occurs, an exempt agricultural user will be unable to resist the claim to water of any licensee, even if the licence was obtained long after the traditional agricultural use began and after the Water Act came into force. ${ }^{57}$ The Water Act therefore creates another possibility, which allows an exempt agricultural user to gain priority within three years of the date that the Act comes into force, by obtaining a type of expedited water right known as a registration. ${ }^{58} \mathrm{~A}$ registration can be granted for a maximum of five acre feet per year and also allows the diversion of water only for the purpose of raising animals or applying pesticides to crops. ${ }^{59}$ The Director must issue a registration upon receipt of a completed application, unless the information provided by the applicant is incorrect. $^{60}$ The registration gives a traditional agricultural user priority as of the first known date that water was used for the stated purpose, but no earlier than July 1, $1894 .{ }^{61}$

Report of the Water Management Review Committee (Edmonton: Alberta Environmental Protection, 1995) at 31, Recommendation 31.1.

Water Act, supra note 31, s. 19(1).

Ibid., s. 19(1).

Ibid., s. 73(1), (4).

Ibid., s. 73(2), (3).

Ibid., s. 74(1).

Ibid., s. 28. 
It must be noted that both the exemption and the registration provisions apply only to the use of water to raise animals and to apply pesticides. Other unlicensed agricultural users of water in excess of one acre foot per year, such as small irrigators, must obtain a licence under the Water Act and gain priority in the ordinary way, as of the date of application.

\section{New Licensees}

The Water Act also makes it possible to obtain a licence that closely resembles licences granted under the Water Resources Act, but contains more built-in flexibility. Two particular features of the legislation make new licences more flexible than their predecessors.

In pursuance of a long standing commitment, licences under the Water Act must be issued for a specific term, ${ }^{62}$ in order to avoid the perceived problem created by licences that were issued without term (and treated as perpetual) under the Water Resources Act. Term licences will be renewable almost as of right, ${ }^{63}$ for the Director may refuse renewal, subject to minor exceptions, only on environmental grounds or if the re-issue of the licence would be contrary to the public interest. ${ }^{64}$ The philosophy of this approach is that a Director should not refuse renewal because water is needed for another private purpose, but only where there is an articulated public policy reason to refuse renewal, such as an an unacceptable decline in the level of a particular river or lake. If private users covet the water allocated under an expiring licence because they intend to put the water to a more valuable use, they should in theory resort to the transfer provisions of the new Act to acquire the rights of an existing licensee, if they have been put into operation. ${ }^{65}$

Although new licences will be issued for a term, they continue to enjoy a large measure of security. However, the Act creates further flexibility by allowing the Director to amend new licences unilaterally if, in his or her opinion, there is, or may be "an adverse effect on human health or public safety."166 This section does not provide a significantly greater power than the existing provision, which allows the suspension of any licence in an emergency, though under the Water Resources Act that power must be exercised through Cabinet and requires the payment of compensation. ${ }^{67}$ The ability to amend a licence unilaterally is less wide than in earlier drafts of legislation, which would have allowed an amendment without the licensee's consent in the case of unforeseeable adverse effects on the environment. ${ }^{68}$

Ibid., s. 51(5), which also provides that the expiry date of a licence must be determined in accordance with the regulations.

lbid., s. 59.

Ibid., s. 60(3)(4).

See the discussion on transferability in Part B below.

Water Act, supra note 31, s. 54(1)(v).

Water Resources Act, supra note 16, s. 13.

Discussion Draft, supra note 32, s. 56(1)(c)(iv). 
The Water Act also introduces a new terminology in the process of obtaining a water licence that requires explanation. Water allocation law has long provided security to those whose project requires time to construct, by ensuring that the water right issued at the completion of the project "relates back" to the time of application, ${ }^{69}$ subject to certain limitations. The "relation back" doctrine ensures that the proponent does not lose priority to intervening users who obtain water rights while the project is under construction. Under the Water Resources Act, this process involved granting an interim licence, which authorised the construction of any necessary works ${ }^{70}$ and creating a mandatory right to obtain a final licence, if the works were completed in accordance with the terms of the interim licence. ${ }^{71}$ Under a somewhat opaque scheme, initial applications for licences were given priority according to the date of their filing and numbered in the order in which they were received. ${ }^{72}$ Once a licence was granted, priority disputes were determined according to the number of the licence, ${ }^{73}$ although there was no provision allowing the transfer of the priority number from the initial application to the final licence.

Under the old system, interim licensees were inclined to note that they had a right to divert water and to neglect to take the action necessary to obtain a final licence. They were then in a precarious position, for the rights of interim licensees had a maximum duration of two years ${ }^{74}$ in the ordinary case, although their holders may have performed everything required under the Act except for the formal step of obtaining a licence. Because of sympathy with this position, administrators tended to treat even long standing and technically expired interim licences as fully fledged licences, although it could be argued that technically only the holders of final licences could take advantage of the rules of priority. The Water Act addresses this problem by replacing the former interim licence with a preliminary certificate. The name "preliminary certificate" is less likely to be confused with a licence and it contains only a commitment to allocate water in a future licence. ${ }^{75}$ The Act unequivocally determines priority according to the date of application, ${ }^{76}$ but makes it clear that only those who proceed to obtain licences actually obtain any priority. ${ }^{77}$

\section{B. THE TRANSFER OF WATER RIGHTS}

It was argued earlier in this article that the major defect of the Water Resources Act was that it guaranteed the occurrence of water shortages, by failing to make room for new users or to create incentives for existing licensees to conserve water. ${ }^{78}$ The highly

See e.g. the classic American decision of Ophir Silver Mining Co. v. Carpenter, 4 Nev. 534 (1869).

Water Resources Act, supra note 16, s. 18(1).

Ibid., at s. 33.

Ibid., s. 11(2).

Ibid., s. 35(1).

Ibid., s. 18(2).

Water Act, supra note 31, s. 66(4)(b).

lbid., s. 29.

Ibid., ss. 30, 66(4)(b)(I).

See text accompanying notes $21,22$. 
restrictive rules of the present legislation, which in practice prevent the transfer of water rights apart from the land or undertaking in respect of which they were issued, are undoubtedly the source of this critical failure in policy.

Suggestions to allow the transfer of water rights enjoyed a chequered career during the reform process. The first comprehensive outline of issues pointed out that rights held under existing licences could not easily be transferred to new users or locations and sought public input. ${ }^{79}$ Initially, public comments on the question of transferability were described as "divided" 80 and they recorded both a clear recognition of the benefits of transferability and fears about the sale of water rights ${ }^{81}$ and the consequences of transfers for the agricultural industry. ${ }^{82}$ The Newsletter that accompanied the Discussion Draft of the legislation suggested that transfers were one of four measures by which the government intended to "promote and encourage the conservation of water." ${ }^{83}$ The Discussion Draft itself proposed a voluntary transfer system to allow licensees to transfer all or part of the allocation held under their licences. ${ }^{84}$ Transfers were to be supervised by the government and essentially subject to the same considerations as an initial application for a new water licence. ${ }^{85}$

Following the publication of the Discussion Draft, a shift in the public mood appeared to occur. Public review sessions of the proposed legislation were held in fourteen locations throughout the province and interest groups participated in a two day workshop. After input had been received, the Water Management Review Committee noted that there had been "strong opposition from the public" ${ }^{186}$ regarding the transfer provisions. Some evidence suggests that opposition was centred in northern Alberta, where significant transfers of water would be unlikely to occur, and that transfers are widely supported in southern Alberta, where they are needed. ${ }^{87}$ Despite its perception that public opinion was negative, however, the Water Management Review Committee recognised that a voluntary transfer system might have favourable effects, "including the outcomes of efficient and sustainable water use, healthy and sustainable aquatic and riparian eco-systems, and sustained opportunities for economic benefit." ${ }^{88}$ As a result, the Committee recommended the retention of a transfer system, subject to significant restraints, ${ }^{89}$ which are faithfully recorded in the Water Act.

Water Management in Alberta: Challenges for the Future (Edmonton: Alberta Environment, 1991) at 16.

Water Management in Alberta: Summary of Public Comments, July to December 1991 (Edmonton: Environment Council of Alberta, Water Resources Commission, 1992) at 45-46.

Ibid.

Report of the Water Management Review Committee (Edmonton: Alberta Environmental Protection, 1995) at 48 [hereinafter Water Management Review Committee Report].

See Newsletter, supra note 27 at 3.

Discussion Draft, supra note 32, s. 81.

Ibid., ss. 82(2), (4).

Supra note 82 at 48.

Alberta Cattle Commission, Alberta Cattle Feeders' Assoc., Alberta Pork Producers Development Corp., Alberta Poultry Industry Council, Alberta Milk Producers, Report on Bill 5I - Water Act (January, 1996) at iii-iv.

Ibid.

Ibid. 
The underlying philosophy of the Water Act is that all water licences are attached to the land in respect of which they were issued and can be severed only under the transfer provisions. ${ }^{90}$ The rights to use water for household purposes and for traditional agricultural purposes can only be transferred with the land to which they are attached, because the transfer provisions apply only to allocations of water held under a licence. ${ }^{91}$ Similarly, a registration is specifically attached to the land in respect of which it is issued and runs with the land, although the Cabinet has the power to sever a registration from the land to which it is appurtenant. ${ }^{92}$

The Water Act contains general provisions similar to those found in the Discussion Draft to allow the transfer of an allocation held under a water licence if an application is made and if there is no adverse effect on the environment or on the rights of others. ${ }^{93}$ However, following the recommendation of the Review Committee, ${ }^{94}$ the Act provides that an application can be considered only if the ability to transfer an allocation of water in the relevant region has been authorized in an approved water management plan or, if there is no applicable plan, by Cabinet order. ${ }^{95}$ As an approved water management plan itself requires Cabinet adoption, ${ }^{96}$ it is clear that it will be some time before any transfers of water rights can occur in Alberta.

As much of the first portion of this article argued that the absence of any realistic possibility of transferring water rights was a fatal flaw in Alberta water law, candour would seem to require the writer to dismiss this portion of the Water Act as an abject failure. In one respect, the Act is even less flexible than its predecessor, for it does not include the limited ability to transfer water rights under the statutory list of preferential uses. ${ }^{97}$ The Water Act does not allow any transfer of an allocation held under a water licence without resort to the Cabinet, either in the form of an approved water management plan or a special order.

On closer reflection, however, such a negative view would not be justified. It is important that the Water Act contains the elements of a workable system to allow the transfer of a water allocation apart from the land in respect of which it was issued. All that is required to activate this system is Cabinet approval of a water management plan authorizing transfers in a particular area of the province. Although this is a matter of speculation, political, economic and environmental factors may make it inevitable that such plans will be approved, for there is no other practical method of accommodating growth and diversification in a large part of Alberta. As yet, there is no experience with the approval of water management plans, although the Alberta Water Resources Committee produced a comprehensive Report on Water Management in the South

Water Act, supra note 31, s. 58.

Ibid., s. 81(1).

lbid., s. 75 .

lbid., ss. 81, 82(3).

Water Management Review Committee Report, supra note 82 at 48, Recommendation no. 48.

Water Act, supra note 31, s. 81(7).

Ibid., ss. I(g), 11.

See discussion in Part II, above. The transfers under this list of preferential uses required only the approval of the Minister, rather than the Cabinet. 
Saskatchewan River Basin in $1985,{ }^{98}$ which could easily be a prototype for future approved water management plans. Because it covers virtually the whole of Alberta south of Red Deer, and all of the chronically water-short areas, the simple inclusion of an authorisation for the transfer of water rights in a future plan of this nature would allow transfers in those regions where they are most needed and most supported. If approved water management plans fulfil this role, the Act need not be characterised as an intolerable straitjacket on water allocation. Instead, it can become a critical safety valve to allow the transfer of water rights without the necessity of returning to the Legislature to seek statutory amendments.

\section{ENVIRONMENTAL PROTECTION}

The Water Resources Act dealt with the allocation of water rights for the primary purpose of encouraging consumptive use. It made few references to the role of environmental protection in water management decisions and no mention at all of the relationship between the Act and the Environmental Protection and Enhancement Act.

On critical matters of provincial environmental policy, the Water Act addresses two issues of major public concern. It prohibits licences that authorize either the transfer of water between major river basins or, except for processed or municipal water, the transfer of water outside of Canada unless authorized by a special Act of the Legislature. ${ }^{99}$ In two remarkable strokes, the $A c t$, as far as the doctrine of parliamentary sovereignty allows, ${ }^{100}$ has disposed of the most emotional and controversial questions in water management.

The procedure for issuing licences, which was almost entirely discretionary under the Water Resources Act, is altered because the Water Act now specifies the factors which may be addressed by the Director in considering an application and includes for the first time specific references to environmental considerations. ${ }^{101}$ The Water Act requires the Director to consider any matters or factors specified in an approved water management plan in deciding whether to issue a licence. ${ }^{102}$ Although this type of plan is clearly a major document, as it must be approved by Cabinet, ${ }^{103}$ it allows a

9 Water Management in the South Saskatchewan River Basin (Edmonton: Alberta Water Resources Commission, 1986). The Report took into account public hearings in 1984 and briefs submitted in 1985, see ibid. at 121, 128-9.

Water Act, supra note 31, s. 46 (prohibition of water export); ibid., s. 47 (prohibition of inter-basin transfers). For a discussion of the validity of the prohibition on water exports, see D.R. Percy, "Provincial Water Law and International Trade" (1996) Il Environmental Law Centre News Brief 2 at 8.

In very unusual terms, the Act prohibits licences for water export or inter basin transfers unless authorized by a special Act of the Legislature: Water Act, supra note 31, ss. 46(2), 47; and imposes consultation requirements prior to the introduction of such legislation: ibid., s. 48. These sections are undoubtedly signals of a serious legislative intention. However, as parliamentary sovereignty prevents the $A C t$ from binding subsequent Legislatures, both exports and inter-basin transfers could be allowed by a simple repeal of ss. 46-48. Ibid., s. 51(4).

102 Ibid., s. 51(a).

103 Ibid., s. 11; see also text accompanying notes $97,98$. 
planning exercise, such as the Report on Water Management in the South Saskatchewan Basin, ${ }^{104}$ to play a major role in allocation decisions once Cabinet approval has been obtained.

It can be objected that a Director could merely pay lip-service to an approved plan, by considering and rejecting its recommendations, and that consideration of other environmental factors is only discretionary. However, in the past, administrators have apparently been reluctant to rely heavily on river basin plans or environmental factors because they are not mentioned in the statute. The specific direction to examine these matters and the ability of objectors to submit to the Environmental Appeal Board a Notice of Objection to the issue of licences and preliminary certificates ${ }^{105}$ will make it difficult for a Director to ignore recommendations in an approved water management plan without articulated reasons. The same appeal mechanism increases the likelihood that proper consideration will be given to environmental issues.

The Water Act also allows the Director to refuse any further applications for licences in fully allocated streams. ${ }^{106}$ This provision legitimizes the present practice of declaring a moratorium on licensing in heavily allocated areas, although it must be noted that even under the Water Act, moratoria can only be issued for a fixed period and not indefinitely. ${ }^{107}$

The ability of the Director to take into account environmental factors in making allocation decisions and to declare a moratorium provides a method of protecting instream flows in rivers that are not fully allocated. In addition, the Minister may now reserve unallocated water for any purpose, ${ }^{108}$ including the protection of instream flow needs, and the Minister may explicitly retain the reserved water indefinitely. ${ }^{109}$

The Water Act thus allows the protection of instream flows by a variety of mechanisms where rivers have not yet been fully licensed. It is much more difficult to restore instream flows in basins that are already heavily allocated. In these circumstances, a government is usually faced with the decision of unilaterally limiting or expropriating the rights of existing licensees or abandoning attempts to restore acceptable levels of flow. The line of least resistance (and political experience in all similar jurisdictions) suggests that in this competition, the instream needs of the river

Supra note 98. See also supra notes 23,24 and accompanying text.

Water Act, supra note $31, \mathrm{~s}$. 115 . The Notice of Objection in these circumstances can be filed by the applicant or others who are directly affected by the decision: s. 115(1)(b)(c). In some cases, the directly affected party must first have submitted a Statement of Concern under ss. 109, $115(1)(b)(1), 115(1)(c)(I)$ of the Act.

lbid., s. 53.

Ibid., s. 53(1).

Ibid., s. 35(1)(b). The Water Resources Act, supra note 16, s. 12(1) allowed the reservation of water only so that the Lieutenant Government in Council could determine how it might be used to the best advantage and contemplates its subsequent allocation to applicants. For the background of the reservation power, see Percy, supra note 4 at 152-53.

Water Act, ibid., s. 35(3). 
will inevitably take second place. ${ }^{110}$ The Water Act seeks to unlock this Gordian knot by allowing some water to be dedicated to instream needs if and when water rights are transferred. Under S. 83, the Director may withhold up to ten percent of any water transferred in order to protect the aquatic environment or to implement a water conservation objective, if the holdback is authorized in an approved water management plan."' Once water has been held back, it cannot be licensed subsequently for any consumptive use. ${ }^{12}$

The water holdback mechanism can be criticised as a timid response to the problem of restoring instream flows, particularly because it can be invoked only where authorized in an approved water management plan. However, it must be acknowledged that the notion of any holdback for environmental reasons without compensation remains controversial ${ }^{113}$ and that it may have been necessary to include the authorisation of holdbacks in an approved plan in order to retain any holdback provisions in the Act. The Act represents only a small step in the direction of restoring instream flows in allocated rivers, but it is perhaps the only step which has a chance of success. Its unusual virtue is to allow the possibility of net gains to all sides. The transferor of water is allowed to realize a benefit through sale or lease, the need of the transferee is satisfied and the river system benefits in exchange for each side taking advantage of gains that were previously prohibited.

Finally, the Water Act gives explicit recognition to the fact that decisions on water quantity allocation can also affect water quality. For example, the grant of a licence to the operator of a pulp mill or to an irrigator can either reduce the assimilative capacity of the river or impair water quality directly because of the condition of return flows. Section 5 of the Act explicitly requires the Director to refer specified projects of this nature for review under the Environmental Protection and Enhancement Act ${ }^{14}$ and links water allocation decisions to the environmental assessment requirements of that legislation. ${ }^{115}$

\section{CONCLUSION}

The Water Resources Act affects the life of most people, although it is not well known either to lawyers or to ordinary citizens. Many citizens are unaware even of the existence of the legislation, probably because they obtain water indirectly, from large licensees such as municipalities or irrigation districts and only the licensees deal directly with the government. Lawyers have traditionally encountered the Act infrequently, probably because disputes over water were rare when water was in

D.R. Percy, Legal Issues in Implementing Instream Flow Allocations and the Transferability of Water Rights in Alberta Environment, Agriculture, Forestry, Lands and Wildlife, Water Resources Commission, Tourism, Parks and Recreation, Municipal Affairs, Instream Flow Needs, Seminar Proceedings (1992) at 241, 249.

III Water Acl, supra note 31, s. 83(1).

112 Ibid., s. 83(3).

113 Report of the Water Management Review Committee, supra note 82 at 50.

114 Water Act, supra note 31, s. 5(1).

11 Ibid., s. 16. 
abundant supply. However, as competition for increasingly scarce water has arisen in the southern regions of the province, much more legal attention has been paid to how licences are granted, the rights of licensees and the management of water by the government. It is therefore necessary to appraise the new Water Act briefly from the viewpoint of both the lawyer and the citizen.

From a legal perspective, the Water Act is initially intimidating. It is nearly three times longer than its predecessor and contains almost twice as many sections. In part, the legislation is lengthy because water law is a complex subject. The Water Act deals with rights that have vested in varying forms for over a century and addresses the notoriously difficult topics of managing and establishing rights in flowing water. In part, the wide scope of the Water Act results from its relationship with the Environmental and Protection Enhancement Act. At the beginning of the reform process, there was much discussion of whether the Water Act should be an independent statute or enacted as an additional chapter to environmental legislation. ${ }^{116}$ Once it was decided to retain a separate Water Act, it became necessary to repeat provisions equivalent to those found in the Environmental Protection and Enhancement Act dealing with the notices of various applications, objections, appeals and especially enforcement. The Water Resources Act was hopelessly inadequate in all of these areas and the need to deal with them takes up approximately the second half of the Water Act. The first half of the Act essentially sets out the rules relating to the four different types of water rights, approvals (which regulate activities such as culverts and bridges that are carried on in and around bodies of water, but do not involve diversion), ${ }^{117}$ priority of rights and transferability. These sections are not difficult to follow, but they are long because of the tendency of modern environmental legislation to repeat for the sake of absolute clarity the rules for the issue and cancellation of each type of instrument created by the $A c t$. By the legalistic test, the $A c t$ is effective, though hardly elegant.

As far as the citizen is concerned, the Review Committee set out a relevant criterion for judging the merit of the Act. The Committee wondered, if Albertans were asked in 2035, why water policy and legislation drafted in 1995 continued to be useful and successful, what would they say? What ultimate results would they want the legislation to achieve? ${ }^{118}$

The reform of water law in Alberta and elsewhere involves highly charged political issues and the reconciliation of interest groups which appear to be unalterably opposed. Against this reality the Act is reasonably successful. The Water Resources Act dealt with the problems of the first part of this century and the Water Act contains all the powers necessary to deal with the totally different concerns of the early twenty-first century. However, before it can be stated with any confidence that Albertans in 2035 will feel that the Water Act has served them well, a commentator will have to be satisfied that the powers in the Act will be exercised. The radical changes that have

118 Report of the Water Management Review Committee, supra note 82 at 1. 
affected agriculture, trade and society as a whole in Alberta and Canada over the last decade demand present and future flexibility in the allocation of resources and a continued willingness not to defend interests merely because they are entrenched. The goal of allowing resources to move to their most highly valued uses, which is now reflected in many other aspects of government policy, will only be fulfilled in water policy if the adoption of approved water management plans quickly removes the restrictions on transferability of water rights. Otherwise, the Act will fail the citizen of the next century miserably. If the model citizen of 2035 is from Calgary, the availability of transfers will be of particular interest, as the city's water rights are said to be adequate until 2050. ${ }^{119}$ As the Bow River is already largely allocated, the ability to acquire water rights from others will by then be central to Calgary's future.

It can also be assumed that the citizen of the next century will demand environmental responsibility and will be dissatisfied if the Water Act has not protected the province's water resources. If the $A c t$ fails in this area, it will have only paved the way for more radical and disruptive legislation in the future. This possibility can be avoided if the $A c t$ is allowed to restore water to stressed river basins, through the exercise of the holdback power upon the transfer of water rights, and if the powers to protect the aquatic and riparian environment are immediately exercised in less heavily allocated basins. Experience in all jurisdictions shows that it is difficult to restore instream flow levels once rivers become fully utilized. This danger can be avoided if planners do not focus all of their attention on the intractable problems of heavily licensed southern rivers. They must also consider quickly establishing threshold levels for instream flows in central and northern basins. ${ }^{120}$ The initial instream flow levels need not be scientifically perfect, and they are likely to allow considerable room for the consumptive use of water in the short term. If they are swiftly established, they will prevent over-allocation from occurring until more detailed studies of instream flow requirements are carried out.

It is, therefore, impossible to assure future citizens that the Water Act will achieve the results that they would wish to see. The Act provides the framework in which those results can occur, but only if its powers are vigorously exercised. Calgary's Point of View" (Oral Presentation to C.W.R.A.A.I.P.A. Fall Conference, 20 November 1989). 